\title{
COXEN Score 8
}

National Cancer Institute

\section{Source}

National Cancer Institute. COXEN Score 8. NCI Thesaurus. Code C128205.

A score of 8 on the COXEN Sensitivity Scale. 